\title{
Medical care costs incurred by patients with smoking-related non-small cell lung cancer treated at the National Cancer Institute of Mexico
}

\author{
Oscar Arrieta ${ }^{1,3}$, Roger Humberto Quintana-Carrillo², Gabriel Ahumada-Curiel ${ }^{1}$, Jose Francisco Corona-Cruz ${ }^{1}$, \\ Elma Correa-Acevedo ${ }^{1}$, Juan Zinser-Sierra ${ }^{3}$, Dolores de la Mata-Moya ${ }^{1}$, Alejandro Mohar-Betancourtt ${ }^{4,5}$, \\ Vicente Morales-Oyarvide ${ }^{1}$ and Luz Myriam Reynales-Shigematsu²*
}

\begin{abstract}
Background: Smoking is a public health problem in Mexico and worldwide; its economic impact on developing countries has not been well documented. The aim of this study was to assess the direct medical costs attributable to smoking incurred by lung cancer patients treated at the National Cancer Institute of Mexico (INCan).

Methods: The study was conducted at INCan in 2009. We carried out a cost of illness (COI) methodology, using data derived from an expert panel consensus and from medical chart review. A panel of experts developed a diagnostic-therapeutic guide that combined the hospital patient pathways and the infrastructure, human resources, technology, and services provided by the medical units at INCan. Cost estimates in Mexican pesos were adjusted by inflation and converted into US Dollars using the 2013 FIX exchange rate for foreign transactions (1 USD $=13.06$ Mexican pesos).

Results: A 297 incident cases diagnosed with any type of lung cancer were analyzed. According to clinical stage, the costs per patient were 13,456; 35,648; 106,186; and 144,555 USD, for lung cancer stages I, II, III, and IV respectively. The weighted average annual cost/patient was and 139,801 USD and the average annual cost/patient that was attributable to smoking was 92,269 USD. This cost was independent of the clinical stage, with stage IV representing $96 \%$ of the annual cost. The total annual cost of smoking-related lung cancer at INCan was $19,969,781$ USD.

Conclusions: The medical care costs of lung cancer attributable to smoking represent a high cost both for INCan and the Mexican health sector. These costs could be reduced if all provisions established in the Framework Convention of Tobacco Control of the World Health Organization were implemented in Mexico.
\end{abstract}

Keywords: Non-small cell lung cancer (NSCLC), Tobacco, Medical care cost, Chemotherapy cost

\section{Introduction}

Smoking is a worldwide primary public health problem. It has been estimated that approximately 1.2 billion people smoke worldwide, and half of them will die of diseases caused by smoking [1]. Currently, close to six million smoking-related deaths occur per year. It has been calculated that this number will increase to eight million deaths

\footnotetext{
* Correspondence: Ireynales@insp.mx

${ }^{2}$ Tobacco Control Research Department, Center for Population Health

Research, National Institute of Public Health, Cuernavaca, Mexico

Full list of author information is available at the end of the article
}

by the year 2030 , of which $80 \%$ will occur in low- and medium-income countries [2].

The harmful effects of smoking on individual and population health, as well as its economic consequences, are well described in the international bibliography [3-7].

However, its effects on the economy of developing countries have not been properly documented, creating a shortage of scientific information for promoting the correct implementation of the Framework Convention

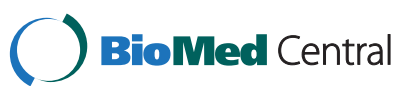

(c) 2014 Arrieta et al.; licensee BioMed Central. This is an Open Access article distributed under the terms of the Creative Commons Attribution License (http://creativecommons.org/licenses/by/4.0), which permits unrestricted use, distribution, and reproduction in any medium, provided the original work is properly credited. The Creative Commons Public Domain Dedication waiver (http://creativecommons.org/publicdomain/zero/1.0/) applies to the data made available in this article, unless otherwise stated. 
of Tobacco Control of the World Health Organization (WHO-FCTC) in Mexico [8].

Lung cancer (LC) is the main cancer-related cause of death worldwide in both men and women [9-11]. It has been estimated that in 2013, there will be 228,190 new LC cases $(118,080$ in men and 110,110 in women) and a total of 159,480 deaths due to LC $(87,260$ in men and 72,220 in women) in the United States [9]. Considering that up to $85 \%$ of these tumors are associated with smoking, their incidence has increased in a sustained fashion since 1970. This increase is attributed to the increase in smoking, especially among women [10,12-16]. A total of 9,148 new cases and 8,807 deaths due to LC were registered in Mexico in 2008 [10].

LC is classified into two large groups: small cell (SCLC) and non-small cell (NSCLC) lung cancer. The latter represents close to $90 \%$ of total LC cases, of which more than $95 \%$ of cases are diagnosed at advanced stages in our country $[17,18]$ and have only a $16 \% 5$-year survival rate $[10,15,17-20]$. While the research and development of new therapeutic schemes improve patient quality of life and survival, they also cause a dramatic increase in treatment costs [21-24].

The National Cancer Institute of Mexico (INCan, for its initials in Spanish) works as the reference site for patients with the most important types of cancer at a national scale. It is implemented with all the necessary human and material resources to provide comprehensive and high quality care for cancer patients. The goal of this study was to assess the direct medical care costs of NSCLC at the INCan that are attributable to smoking.

\section{Materials and methods Study population}

To estimate the direct health care costs of Lung cancer at Incan*, we carried out a cost of illness (COI) methodology, using incidence approach. During 2009, 297 incident cases with any type of NSCLC were admitted. The patient inclusion criteria were as follows: $\geq 35$ years of age, current/past smokers and non-smokers at the time of diagnosis, and subject to medical follow-up for at least one year after diagnosis. All patients were classified as stage I, II, III, or IV, according to the TNM classifications of the 6th edition of the American Joint Committee on Cancer (AJCC) and the Union for International Cancer Control (UICC) [25].

\section{Experts' panel consensus}

The technique based on the nominal group or expert panel consensus [26] was used to define the medical and clinic characteristics of a patient diagnosed with NSCLC, which are relevant for cost estimations. For that purpose, a diagnostic-therapeutic guide was defined. This guide combined the hospital patient pathways and the infrastructure, human resources, technology, and services provided at the INCan.

To do so, the following seven events were defined:

1. Outpatient care

2. Operating room care (surgery)

3. Regular (non-critical care) hospitalization

4. Intensive Care Unit (ICU) hospitalization

5. Chemotherapy administration

6. Radiotherapy treatment

7. Palliative care

It is noteworthy that although there is a protocol for smoking cessation in the first and second levels of healthcare including brief advice and psychotherapeutic support; there is not a specialized and integrated protocol for giving up smoking cessation of patients with cancer.

Similarly, for each clinical stage, the human and material resources required were specified in terms of quantity and frequency. The medical and nursing procedures for the medical care of each patient were further defined. The panel of experts established the units of measure, the quantity used, and the duration of the prescribed medication.

\section{Cost estimates}

The finance department at the INCan provided cost information regarding the different medical services, materials, medications, and human resources, as well as the current fixed costs of the institution. The cost assessment was conducted from the perspective of the healthcare service provider using the cost of illness (COI) methodology. To determine the costs, a micro-costing model was developed, and the total costs of the disease were incorporated from the unit costs of the services provided using the bottom-up methodology $[27,28]$. Cost estimates in Mexican pesos were adjusted by inflation and converted into US Dollars using the 2013 FIX exchange rate for foreign transactions ( 1 USD $=13.06$ Mexican pesos).

\section{Medical event cost estimates}

The unit cost estimates determining the total cost of the disease were calculated using an accounting model $[29,30]$. The accounting model included the annual salary of the human resources, which included social benefits. The capital costs (equipment and installation) were depreciated and prorated according to the equivalent annual cost (EAC) methodology [27,31]. The cost estimates of the medications and required materials were conducted based on the INCan's consolidated. The unit of measure was hour/activity (hour/consultation, hour/surgery, hour/regular hospitalization, hour/ICU hospitalization, hour/chemotherapy, hour/radiotherapy, and hour/palliative care). 
The following equation was applied to estimate the cost of medical events:

$$
M E C_{\text {esptnr }}=\sum_{r=1}^{n_{2}} R U_{\text {esptnr }} * U C_{\text {esptnr }}
$$

Where:

$$
\begin{aligned}
M E C_{\text {esptnr }}= & \text { Medical event cost per patient, according to } \\
& \text { the type of disease }
\end{aligned}
$$

\section{$d=$ Disease}

=Disease severity: Stage I, II, III, and IV

$p=$ Number of patients

$\mathrm{t}=$ Type of medical event: outpatient, operating room, regular hospitalization, ICU hospitalization, chemotherapy, radiotherapy, or palliative care

$n=$ Number of medical events $\{$ Number of events $/ l=i\}$

$\left\{1,2, \ldots n_{2}\right\}$

$=$ Resources used during medical care

\section{Average cost estimate per case}

After estimating the costs of the medical event, the average annual cost per patient by NSCLC disease stage was calculated. The average cost per patient according to NSCLC stage was calculated using the following equation:

$$
M E A C_{e s}=\frac{\sum_{p=1}^{n_{1}} \sum_{n=1}^{n_{2}} M E C_{\text {esptnr }}}{n_{\text {est }}}
$$

Where:

$M E A C_{\text {est }}=$ Medical event average cost

$M E C_{\text {esptnr }}=$ Medical event cost for one patient, according to disease severity

$=$ Number of patients $\left\{1,2 \ldots n_{1}\right\}$

$=$ Number of medical events $\{$ Number of events $/ l=i\}$

$\left\{1,2, \ldots n_{2}\right\}$

$n_{\text {est }}=$ Number of patients undergoing the event,

according to disease severity

\section{Case-specific cost estimate, according to disease severity}

Once the unit cost of the medical event was obtained, the average annual cost per case was calculated using the frequency of event occurrence reported by the panel of experts. The average cost per patient according to the clinical stage of the disease was obtained using the following equation:

$$
A C D S_{e s} \frac{\sum_{p=1}^{n_{1}} \sum_{t=1}^{8} \sum_{n=1}^{n_{2}} M E C P_{\text {esptnr }}}{n_{\text {es }}}
$$

Where:

$A C D S_{e s}=$ Average cost, according to disease severity $M E C P_{\text {esptnr }}=$ Medical event cost per patient, according to the stage of the disease

$=$ Patients $\left\{1,2, \ldots n_{1}\right\}$

$t=$ Type of medical event: outpatient, operating room, regular hospitalization, ICU hospitalization,

chemotherapy, radiotherapy, or palliative care

$=$ Number of medical events $\{$ Number of events $/ l=i\}$

$\left\{1,2, \ldots n_{2}\right\}$

= Number of patients per event, according to disease severity

\section{Total cost of disease at the INCan}

The total cost was obtained by multiplying the average annual cost per patient by the number of new NSCLC cases in 2009. These costs were weighted according to the patient distribution by medical event and disease stage. In addition, while the study ran between 2009 and 2010, costs were adjusted for inflation and estimated at USD 2013. The total cost of the disease was calculated using the following equation:

$$
T C D_{e}=\sum_{s=1}^{6} A C D S_{e s} * N_{e s}
$$

Where:

$T C D_{e}=$ Total cost of disease

$A C D S_{\text {es }}=$ Average cost, according to disease severity

$N_{e s}=$ Number of patients per event, according to disease severity

\section{Cost of disease attributable to smoking}

The Population Attributable Fraction (PAF) represents the proportion of NSCLC cases that can be attributed to a causal factor, which in this case is smoking [32-35]. Reynales-Shigematsu et al [36] previously estimated the smoking-attributable fraction (SAF) for NSCLC in the Mexican population ages 35 to 65 that were covered by the Mexican Social Security Institute (IMSS, for its initials in Spanish). The weighted SAF value for NSCLC estimated for Mexico was 0.66 (CI 
0.58-0.73). This value was used to estimate the NSCLC costs associated with smoking.

Total smoking-attributable NSCLC cost at the INCan Finally, to calculate the cost associated with smoking, the NSCLC SAF was multiplied by the total cost of NSCLC using the following equation:

$$
S D C_{e}=T C D_{e} * S A F_{e}
$$

Where:

$S D C_{e}=$ Smoking-related cost of disease

$T C D_{e}=$ Total cost of disease

$S A F_{e}=$ Smoking-attributable fraction

\section{Results}

Out of a total of 297 patients diagnosed with NSCLC, $1.2 \%$ of the cases were detected at an early stage (I and II); $16 \%$ had locally advanced disease (stage III); and $82 \%$ presented with metastatic disease (stage IV).

The number of patients undergoing different medical events is described in Table 1.

The average length of stay for hospitalized patients with NSCLC was 22 days. The average daily medical care cost per patient was 3,328 USD (1,580-4,501 USD), out of which 2,196 USD (1,043-2,971 USD) was attributable to smoking. The total cost of hospitalization represented only $2 \%$ of the total medical care cost (TMCC) attributable to smoking. Chemotherapy was the most costly treatment for patients with stage III and IV NSCLC, with an average annual medical care cost (AAMCC) of 47,768 USD and 83,868 USD, respectively.

The AAMCC per NSCLC patient was 139,801 USD (13,456-144,555 USD), and the AAMCC per NSCLC patient attributable to smoking was 92,269 USD (8,88195,406 USD), disregarding the clinical stage of the disease.

The patients with stage III and IV NSCLC were the most costly, reaching an AAMCC of 106,186 USD and 144,555 USD, respectively. However, surgical procedures and chemotherapy treatment were the most costly for patients in stages I and II (Table 2).

For patients with stage I disease, surgical treatment represented $78.7 \%$ of the total cost. For stages II and III, surgical treatment and chemotherapy represented $71.5 \%$ and $65.1 \%$ of the total annual cost, respectively. For stage IV, outpatient consultations and chemotherapy represented $75.0 \%$ of the total costs (Figure 1).

The TMCC for patients with a first-time diagnosis of NSCLC was 30,257,245 USD, while the TMCC attributable to smoking was 19,969,781 USD (Table 3).

For the same calendar year, stage IV LC due to smoking was the most costly, representing $63.6 \%$ of the TMCC.

An interesting fact is that the medical care costs in public hospitals, such as the INCan, are split between
Table 1 NSCLC Total medical events at INCan in 2009

\begin{tabular}{ll}
\hline Event & No. \\
\hline Outpatient care & 297 \\
Operating room care (surgery) & 20 \\
Regular (non-critical care) hospitalization & 192 \\
Intensive Care Unit (ICU) hospitalization & 10 \\
Chemotherapy administration & 240 \\
Radiotherapy treatment & 168 \\
Palliative care & 240 \\
\hline
\end{tabular}

the patient and the institution. The division is based on a payment level category assigned to the patient: the patient's payments increase proportionally with the treatment costs, thus decreasing the institutional costs.

Despite some patients being classified as level 1, the patient's cost percentage is approximately $70 \%$, given that medication costs (which account for most of the costs) are not subsidized by the INCan (Figure 2).

\section{Discussion}

This study provides the first detailed cost estimate for the medical care of NSCLC attributable to smoking at an oncology center in Mexico. The results of this study show that the annual costs attributable to smoking are high for patients with newly diagnosed NSCLC, exceeding 18 million USD (235 million Mexican pesos). The medical care costs for recently diagnosed LC patients are mainly due to surgical and chemotherapy treatments.

In Mexico, during 2013, the medical care costs for NSCLC attributable to smoking, as estimated by the Social Security Administration of the Mexican Secretariat of National Defense (SEDENA, for its initials in Spanish), were 2.1 million USD (28.4 million Mexican pesos, calculated based on an exchange rate of 1 USD $=13.06$ Mexican pesos, according to the information provided by the Bank of Mexico [Banxico] for 2013). That same year, the Mexican Institute for Social Security and Services for State Workers (ISSSTE, for its initials in Spanish) estimated the costs associated with NSCLC attributable to smoking to be 2.8 million USD (36.7 million Mexican pesos) [37].

The differences in the total treatment costs for NSCLC in third-level hospitals in Mexico (IMSS, ISSSTE, and SEDENA), which were calculated using the same cost estimate methodology, are mainly due to changes in unit costs and the frequency of use of the different resources. Direct cost accounting varies with the level of human resource specialization, the implementation of diagnostic and treatment guidelines, and the unit costs of medication and equipment (e.g., unit costs for stents) at each institution. Indirect cost accounting varies with the available hospital infrastructure (e.g., number of beds for 
Table 2 Annual average cost according to clinical stage and medical event per NSCLC patient at INCan. 2013

\begin{tabular}{|c|c|c|c|c|c|c|c|}
\hline \multicolumn{8}{|l|}{ Lung cancer stages +} \\
\hline \multirow[t]{2}{*}{ Event type } & I & II & III & \multirow[t]{2}{*}{ IV } & \multicolumn{3}{|l|}{ LC } \\
\hline & \multicolumn{3}{|c|}{ Annual cost average } & & Weighted annual cost average* & Minimum & Maximum \\
\hline Outpatient care & $\$ 1,280.75$ & $\$ 2,948.96$ & $\$ 15,129.26$ & $\$ 24,606.10$ & $\$ 23,623.40$ & $\$ 1,280.78$ & $\$ 24,606.10$ \\
\hline $\begin{array}{l}\text { Regular (non-critical care) } \\
\text { hospitalization }\end{array}$ & $\$ 1,580.50$ & $\$ 4,501.53$ & $\$ 2,892.15$ & $\$ 3,359.66$ & $\$ 3,328.02$ & $\$ 1,580.39$ & $\$ 4,501.53$ \\
\hline Operating room care (surgery) & $\$ 10,595.24$ & $\$ 10,816.84$ & $\$ 21,328.31$ & - & $\$ 11,510.31$ & $\$ 10,595.24$ & $\$ 21,328.31$ \\
\hline $\begin{array}{l}\text { Intensive Care Unit } \\
\text { (ICU) hospitalization }\end{array}$ & - & $\$ 2,723.22$ & $\$ 2,723.22$ & $\$ 2,723.22$ & $\$ 2,723.22$ & & \\
\hline Chemotherapy administration & - & $\$ 14,658.14$ & $\$ 47,768.79$ & $\$ 83,868.53$ & $\$ 81,240.02$ & $\$ 14,658.14$ & $\$ 83,868.53$ \\
\hline Radiotherapy treatment & - & & $\$ 9,245.79$ & $\$ 17,522.05$ & $\$ 16,902.06$ & $\$ 9,245.79$ & $\$ 17,522.05$ \\
\hline Palliative care & - & & $\$ 7,099.35$ & $\$ 12,475.91$ & $\$ 12,192.94$ & $\$ 7,099.35$ & $\$ 12,475.91$ \\
\hline Case total & $\$ 13,456.39$ & $\$ 35,648.68$ & $\$ 106,186.76$ & $\$ 144,555.47$ & $\$ 139,801.87$ & $\$ 13,456.39$ & $\$ 144,555.47$ \\
\hline
\end{tabular}

The cost was estimated in Mexican pesos 2009 and was adjusted by inflation for 2013 using the official INPC and inflation rate established by INEGI http://www.inegi.org.mx/sistemas/indiceprecios/Calculadoralnflacion.aspx.

Currency Dec 2013: USA dollar, 1 dollar = 13.06 Mexican pesos. Exchange according to Bank of Mexico (Banxico) information.

hospitalization purposes, operating rooms, and intensive care units) and the high-cost technology used for diagnostic and treatment procedures. In addition to the aforementioned data, it must be taken into consideration that the analysis of every epidemic must include the disease incidence and prevalence rates, as well as its etiology and its impact on population health. Tobacco addiction can be considered the worst-ever epidemic for humanity. Thus, the most appropriate way to approach it is not only by recognizing its health consequences but also by understanding how the tobacco industry manipulates the most vulnerable groups, altering the image of the disease-causing agent $[12,38]$.
In the last 100 years, lung cancer went from being a medical rarity to the main cause of death from cancer in the world. This increase was achieved by the introduction of smoking into our society during the first half of the 20th century, when the proportion of male smokers was as high as $60 \%[38,39]$. According to the National Addiction Survey of 2011 in Mexico, the prevalence of smokers in the population (ages 12 to 65 ) was $21.7 \%$ [16]. This percentage represents a population of 17.3 million Mexican smokers. In 1989, only 25\% of smokers started smoking at age 12, while in 2011, this fraction had increased to $50 \%$. That same year, 25,383 deaths due to smoking were registered, of which 5,615 were

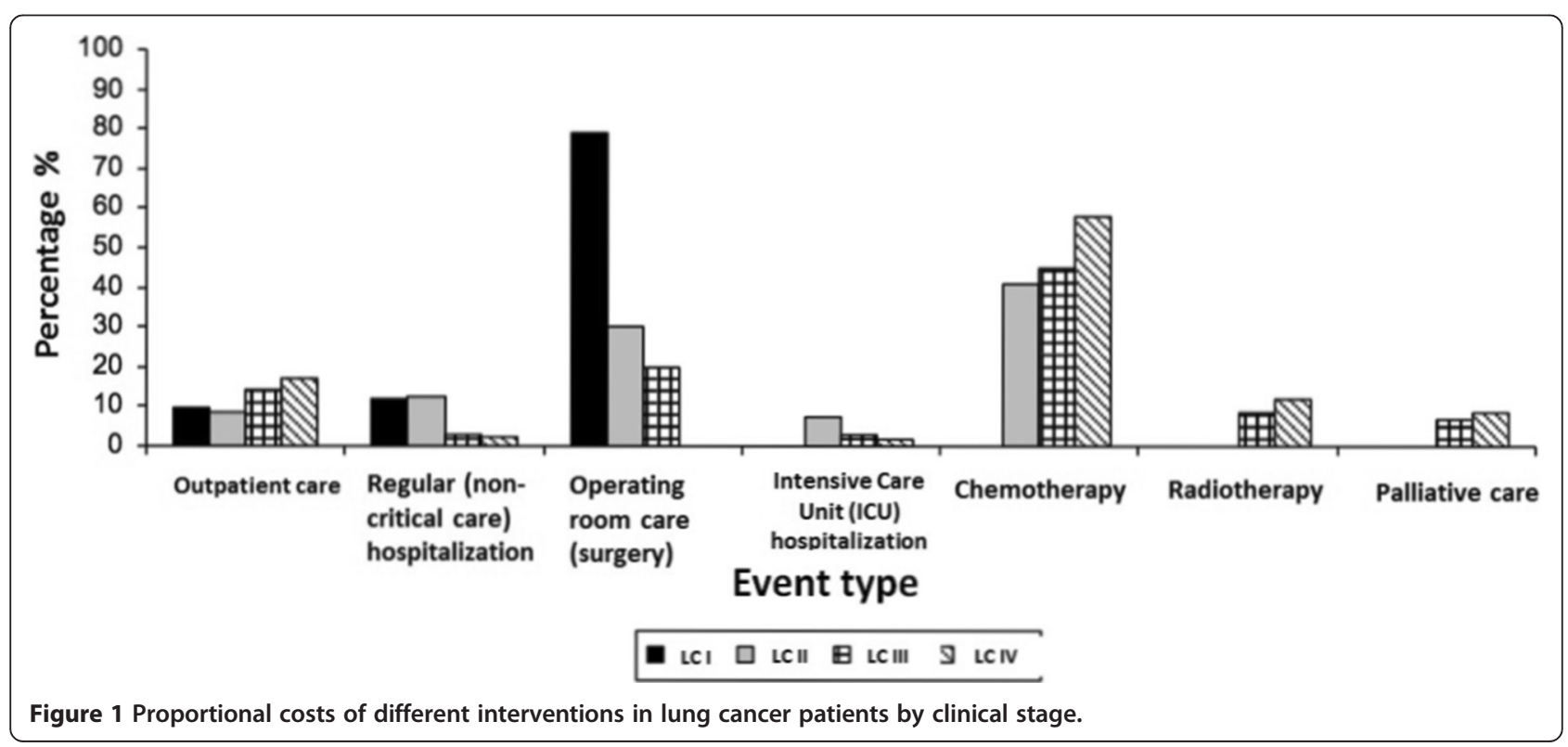


Table 3 Total costs according to NSCLC clinical stage at INCan. 2013

\begin{tabular}{lll}
\hline Stage $^{+}$ & Annual total cost & Annual total cost due to tobacco \\
\hline LC I & $\$ 48,617.17$ & $\$ 32,087.28$ \\
LC II & $\$ 80,957.16$ & $\$ 53,431.72$ \\
LC III & $\$ 985,634.28$ & $\$ 650,518.63$ \\
LC IV & $\$ 29,142,036.54$ & $\$ 19,233,744.07$ \\
Total & $\$ 30,257,245.15$ & $\$ 19,969,781.81$ \\
\hline
\end{tabular}

The cost was estimated in Mexican pesos 2009 and was adjusted by inflation for 2013 using the official INPC and inflation rate established by

INEGI http://www.inegi.org.mx/sistemas/indiceprecios/Calculadoralnflacion.aspx. Currency Dec 2013: USA dollar, 1 dollar $=13.06$ Mexican pesos.

Exchange according to Bank of Mexico (Banxico) information.

${ }^{+}$Structure established by the Lung Cancer experts of the INCan and the CIE-10 2009.

"Obtained with tobacco attributable fraction of $L C$, calculated for national IMSS; 0.66. Reynales et al.

due to cancer. These results suggest that smoking is the main etiological factor for the top 10 causes of morbidity and mortality in Mexico [16].

Despite the existing sub-registry, the Mexican National Institute of Statistics and Geography (INEGI, for its initials in Spanish) reported that in 2008, there were more than 9,000 LC-related deaths in our country. This number represents the second most frequent cause of cancer-related death in males and the third most frequent one in women, after prostate and breast/uterine cancer, respectively [40]. In contrast to developed countries, such as the United States (U.S.) or Europe, where $85 \%$ of LC is associated with smoking, only $66 \%$ of LC cases in our country were found to be due to smoking. While there are other risk factors, such as wood smoke exposure $[18,41]$, secondhand smoke [18,42], and tuberculosis [43], the role of tobacco as a disease-causing agent cannot be overlooked.

If we compare NSCLC to breast and colorectal cancer, where advances in treatment have doubled the patient survival rates $[9,10,44,45]$, the impact of treatment on the survival of patients with NSCLC is limited. In the 1960 s, the 5 -year survival rate was $12 \%$, while it is currently $16 \%$ [42]. Furthermore, smoking is not only associated with LC development but is also strongly linked to genetic alterations within the lung tumors themselves, such as K-Ras mutations [46], which turn them into more aggressive cancers with poor response to treatment [47].

Even if the present study did not take them into account, in recent years, the use of targeted therapies has been shown to improve the survival of NSCLC patients with specific mutations that make them ideal candidates for said treatments [46,48-52]. However, these medications are extremely costly and, generally, poorly accessible to the Mexican population. This problem is particularly serious in a developing country, such as ours, where the cost of medications is similar to their cost in developed countries. For example, the cost of erlotinib $150 \mathrm{mg}$ (an epidermal growth factor receptor [EGFR] inhibitor) is 3,100 USD in the U.S. and close to 3,000 USD in Mexico. However, the minimum daily wage for 2013 in the U.S. is approximately 9 USD/hour [53], while in our country, it is $0.57 \mathrm{USD} /$ hour [54]. This difference deepens the existing inequality for the optimal management of LC patients associated with the cost of these types of therapy.

Worldwide, tobacco control policies have evolved as evidence of the harmful health effects of smoking has arisen. The objectives of these policies are to keep the nonsmoking population from consuming tobacco while helping active smokers quit this habit. These policies include information and education about the risks of smoking, smoking bans in public spaces, blocking smoking advertisements on television, adding warning labels to cigarette packs, and raising taxes on tobacco producers. These public policy measures have decreased smoking in several developed countries $[38,55]$. Unfortunately, the opposite has happened in developing countries, where the number of

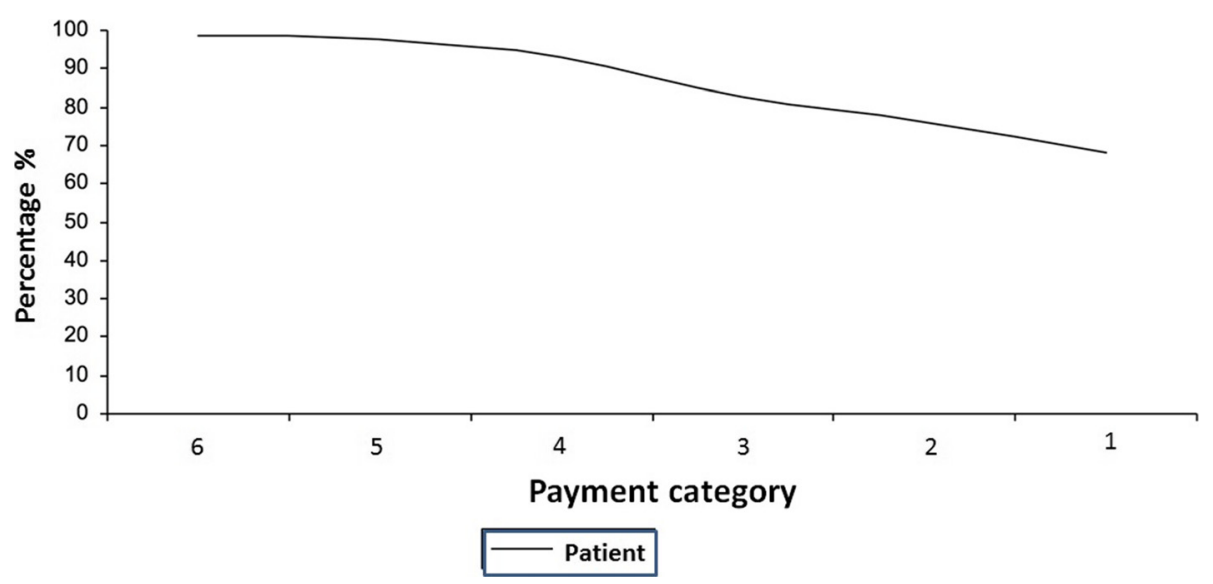

Figure 2 Proportion of lung cancer patients in each payment category at INCan. 
smokers has increased, especially among women and teenagers. This increase is mainly due to the tactics employed by the tobacco industry and the lack of effective public policies [1,8,56-58].

Finally, in order to address the generalizability of the study is is important to mention that, in Mexico, health care is mainly delivered throughout three institutions: the Mexican Institute for Social Security (IMSS), the Institute for Social Security and Services for Civil Servants (ISSSTE) and the Health Department (SSA). The IMSS is responsible for the health care of $40 \%$ of the population, whereas the ISSSTE attends $35 \%$ and the SSA the remaining $25 \%$ of the mexican population. The INCan, belongs to the health department. However, is noteworthy that there are significant differences for NSCLC treatment among those institutions. Also, there are several strengths to this study; it is the first cost estimate study for NSCLC using the COI methodology in a thirdlevel medical service center in Mexico covering the population without social security benefits; employing a more precise methodology for estimating costs, given that it used the information in the medical records of patients. This information allowed a greater precision in the diagnosis and classification of cases, as well as in the actual frequency of use of different medical resources. Our study used financial information to estimate the medical care costs due to smoking at an institutional and national level.

Our results provide a powerful argument that endorses and supports public health policies against smoking. Our cost information is useful and necessary for estimating the national budget and how it will be utilized. The health sector needs to invest in the treatment and prevention of NSCLC over the next decades. Lastly, our results will allow future cost-effectiveness and cost-benefit studies to be conducted, which will allow assessment of the economic impact of tobacco control policies in Mexico over the last 5 years. The medical care costs of NSCLC attributable to smoking at the INCan are high. These increased costs should prompt the authorities to implement strategies and prevention programs following the better practices recommended by the WHO-FCTC. The prevention and control of all modifiable risk factors related to NSCLC (wood smoke, alcohol abuse, and smoking) will not only benefit morbidity and mortality rates but will also represent an important reduction in healthcare costs at a national level.

This study illustrates the high cost of medical care for a disease that is largely attributable to smoking. A malignant tumor can be prevented in more than $80 \%$ of cases. The medical care costs reported in this study are catastrophic for any patient without health insurance. It should be noted that this analysis took only tangible costs into account. Indirect costs due to premature death, early retirement, and loss of productivity, among other factors, were not further studied $[36,37,59]$. In Mexico, it is imperative to implement better and more aggressive tobacco control policies to reduce the number of deaths that are attributable to smoking.

\section{Conclusion}

The medical care costs incurred by patients with lung cancer and a smoking history represent a heavy burden for both the INCan and the Mexican health care system. Efforts to enforce the provisions established in the Framework Convention of Tobacco Control of the World Health Organization should be pursued in order to significantly reduce these costs.

\section{Competing interests}

This project was funded by the Mexican Council Against Tobacco ("Consejo Mexicano para el Control del Tabaquismo", in Spanish). The authors have no financial relationships with the sponsor and have no financial or nonfinancial conflicts of interests pertaining to this manuscript. The publication of study results was not contingent on the sponsor's approval or censorship of the manuscript.

\section{Authors' contributions}

Design and conception of the study: LMRS. Analysis of data: OA, RHQC, GAC, VMO. Interpretation of data: OA, RHQC, GAC, JFCC, ECA, JZS, DMM, AMB, VMO, LMRS. Drafting and revision of the manuscript: OA, RHQC, GAC, JFCC, ECA, JZS, DMM, AMB, VMO, LMRS. Acquisition of data: OA, RHQC, JZS, DMM, ECA, JCC. Final approval of the manuscript: OA, RHQC, GAC, JFCC, ECA, JZS, DMM, AMB, VMO, LMRS.

\section{Author details}

${ }^{1}$ Clinic of Thoracic Oncology, National Cancer Institute of Mexico (INCan), Mexico City, Mexico. ${ }^{2}$ Tobacco Control Research Department, Center for Population Health Research, National Institute of Public Health, Cuernavaca, Mexico. ${ }^{3}$ Medical Oncology Department, National Cancer Institute of Mexico (INCan), Mexico City, Mexico. ${ }^{4}$ Head of the Epidemiology Unit, National Cancer Institute of Mexico (INCan), Mexico City, Mexico. ${ }^{5}$ National Autonomous University of Mexico (UNAM), Mexico City, Mexico.

Received: 30 May 2014 Accepted: 5 December 2014

Published online: 04 February 2015

\section{References}

1. Eriksen M, MacKay J, Ross H: The tobacco atlas. American Cancer Society: Atlanta; 2013

2. Mathers CD, Loncar D: Projections of global mortality and burden of disease from 2002 to 2030. PLoS Med 2006, 3(suppl):e442.

3. Centers for Disease Control and Prevention (CDC): Smoking-attributable mortality, years of potential life lost, and productivity losses-United States, 2000-2004. MMWR Morb Mortal Wkly Rep 2008, 57:1226-1228.

4. Callum C, Boyle S, Sandford A: Estimating the cost of smoking to the NHS in England and the impact of declining prevalence. Health Econ Policy Law 2011, 6:489-508.

5. Ruff LK, Volmer T, Nowak D, Meyer A: The economic impact of smoking in Germany. Eur Respir J 2000, 16:385-390.

6. Neubauer S, Welte R, Beiche A, Koenig HH, Buesch K, Leidl R: Mortality, morbidity and costs attributable to smoking in Germany: update and a 10-year comparison. Tob Control 2006, 15:464-471.

7. Banegas JR, Diez-Gañan L, Bañuelos-Marco B, González-Enríquez J, Villar-Álvarez F, Martín-Moreno JM, Córdoba-García R, Pérez-Trullén A, Jiménez-Ruiz C: Mortalidad atribuible al consumo de tabaco en España en 2006. Med Clinc (Barc) 2011, 136:97-102

8. Jimenez-Ruiz JA, Saenz de Miera B, Reynales-Shigematsu LM, Waters HR, Hernández-Avila M: The impact of taxation on tobacco consumption in Mexico. Tob Control 2008, 17:105-110. 
9. Siegel R, Naishadmham D, Jemal A: Cancer Statistics, 2013. CA Cancer J Clin 2013, 59:225-249.

10. GLOBOCAN 2012 v1.0, Cancer Incidence and Mortality Worldwide: IARC CancerBase No. 11. [http://globocan.iarc.fr]

11. American Cancer Society: Cancer Facts and Figures 2012. Atlanta: American Cancer Society; 2012

12. The MPOWER package: WHO report on the global tobacco epidemic. Geneva: World Health Organization; 2008.

13. Ruiz-Godoy L, Rizo Rios P, Sanchez-Cervantes F, Osornio-Vargas A, GarcíaCuellar C, Meneses García A: Mortality due to lung cancer in Mexico. Lung Cancer 2007, 58:184-190.

14. Valdes N, Sanchez S: El tabaco y las adolescentes: tendencias actuales. Organizacion Panamericana de la Salud: Washington; 1999.

15. Medina F, Salazar M: Frecuencia y patron cambiante del cancer pulmonar en Mexico. Salud Publica de Mex 2000, 42:333-336.

16. Lazcano-Ponce E, Reynales-Shigematsu LM, Guerrero-López CM, VallejoMateos A, Muños-Hernández JA, BarrientosGutiérrez T, Thrasher-La Fontaine J, Arillo-Santillán E, Pérez-Hernández R, Sáenz-de-Miera-Juárez B: Encuesta Nacional de Adicciones 2011: tabaco. Cuernavaca, México: Instituto Nacional de Salud Pública, 2013.

17. Arrieta O, Guzman-de Alba E, Alba-Lopez LF, Acosta-Espinoza A, AlatorreAlexander J, Alexander-Meza JF, Allende-Pérez SR, Alvarado-Aguilar S, Araujo-Navarrete ME, Argote-Greene LM, Aquino-Mendoza CA, AstorgaRamos AM, Austudillo-de la Vega H, Avilés-Salas A, Barajas-Figueroa LJ, Barroso-Quiroga N, Blake-Cerda M, Cabrera-Galeana PA, Calderillo-Ruíz G, Campos-Parra AD, Cano-Valdez AM, Capdeville-García D, Castillo-Ortega G, Casillas-Suárez C, Castillo-González P, Corona-Cruz JF, Correa-Acevedo ME, Cortez-Ramírez SS, de la Cruz-Vargas JA, de la Garza-Salazar JG, et al: Consenso nacional de diagnostico y tratamiento del cancer de pulmon de celulas no pequeñas. Rev Invest Clin 2013, 65(Suppl):S5-S84.

18. Arrieta O, Campos-Parra AD, Zuloaga C, Avilés A, Sánchez-Reyes R, Manríquez ME, Covián-Molina E, Martínez-Barrera L, Meneses A, Cardona A, Borbolla-Escoboza JR: Clinical and pathological characteristics, outcome and mutational profiles regarding non-small-cell lung cancer related to wood-smoke exposure. J Thorac Oncol 2012, 7:1228-1234.

19. Lazcano Ponce EC, Tovar Guzman V, Meneses Gonzalez F, Rascon Pacheco RA, Hernandez Avila M: Trends of lung cancer mortality in Mexico. Arch Med Res 1997, 28:565-570.

20. Medina FM, Barrera RR, Morales JF, Echegoyen RC, Chavarría JG, Rebora FT: Primary lung cancer in Mexico city: a report of 1019 cases. Lung Cancer 1996, 14:185-193.

21. Carlson JJ, Veenstra DL, Ramsey SD: Pharmacoeconomic evaluations in the treatment of non-small cell lung cancer. Drugs 2008, 68:1105-1113.

22. Campos-Parra AD, Cruz-Rico G, Arrieta O: Personalized treatment in non-small cell lung cancer. Rev Invest Clin 2012, 64:377-386.

23. Jäkel A, Plested M, Dharamshi K, Modha R, Bridge S, Johns A: A systematic review of economic evaluations in second and later lines of therapy for the treatment of non-small cell lung cancer. Appl Health Econ Health Policy 2013, 11:27-43.

24. Zeng X, Karnon J, Wang S, Wu B, Wan X, Peng L: The cost of treating advanced non-small cell lung cancer: estimates from the chinese experience. PLoS One 2012, 7:e48323.

25. Sobin LH, Wittekind C: TNM Classification of Malignant Tumours. New York: International Union Against Cancer/Wiley-Blackwell; 2002.

26. Fink A, Kosecoff J, Chassin M, Brook RH: Consensus methods: characteristics and guidelines for use. Am J Public Health 1984, 74:979-983.

27. Eisenberg JM: Clinical economics. A guide to the economic analysis of clinical practices. JAMA 1989, 262:2879-2886.

28. Oostenbrink JB, Koopmanschap MA, Rutten FF: Standardisation of costs: the Dutch manual for costing in economic evaluations. Pharmacoeconomics 2002, 20:443-454.

29. Jones J, Hunter D: Consensus methods for medical and health services research. BMJ 1995, 311:376-380.

30. Mogyorosy Z, Smith P. The main methodological issues in costing health care services: a literature review. York: The University of York Centre for Health Economics; 2005

31. Drummond M, O'Brien B, Stoddart GL, Torrance GW: Metodos para la evaluación económica de los programas de asistencia sanitaria. Madrid: Ediciones Diaz de Santos; 2001.
32. Llorca J, Fariñas-Alvarez C, Delgado-Rodriguez M: Fraccion atribuible poblacional: calculo e interpretacion. Gac Sanit 2001, 15:61-67.

33. Warner KE, Hodgson TA, Carroll CE: Medical costs of smoking in the United States: estimates, their validity, and their implications. Tob Control 1999, 8:290-300

34. Jha P, Chaloupka F: Tobacco Control in Developing Countries. Oxford: Oxford University Press; 2000.

35. Research for International Tobacco Control. At what cost? The economic impact of tobacco use on national health systems, societies and individuals: a summary of methods and findings. Ottawa: RITC Monograph Series No. 1, International Development Research Centre, 2003.

36. Reynales-Shigematsu LM, Rodriguez-Bolaños Rde L, Jiménez JA, JuárezMárquez SA, Castro-Ríos A, Hernández-Avila M: Health care costs attributable to tobacco consumption on a national level in the Mexican Social Security Institute. Salud Publica Mex 2006, 48(Suppl):S48-S64.

37. Reynales LM, Thrasher JF, Lazcano E, Hernandez M: Salud publica y tabaquismo, volumen I. Politicas para el control del tabaco en Mexico. Mexico: Instituto Nacional de Salud Publica; 2012.

38. Samet JM: Tobacco smoking: the leading cause of preventable disease worldwide. Thorac Surg Clin 2013, 23:103-112.

39. Dresler C: The changing epidemic of lung cancer and occupational and environmental risk factors. Thorac Surg Clin 2013, 23:113-122.

40. Instituto Nacional de Estadística, Geografía e Informática, 2009. [www.inegi.org.mx]

41. Arrieta O, Martinez-Barrera L, Treviño S, Guzman E, Castillo-Gonzalez P, RiosTrejo MA, Flores-Estrada D, Téllez E, Gonzalez C, de la Cruz Vargas J, la Rosa CH G-D, Hernandez-Pedro N, Morales-Barrera R, De la Garza J: Wood-smoke exposure as a response and survival predictor in erlotinib-treated non-small cell lung cancer patients. J Thorac Oncol 2008, 3:887-893.

42. Bosetti C, Rodriguez T, Chatenoud L, Bertuccio P, Levi F, Negri E, La Vecchia C: Trends in cancer mortality in Mexico, 1981-2007. Eur J Cancer Prev 2011, 20:355-363.

43. Yu YH, Liao CC, Hsu WH, Chen HJ, Liao WC, Muo CH, Sung FC, Chen CY: Increased lung cancer risk among patients with pulmonary tuberculosis: a population cohort study. J Thorac Oncol 2011, 6:32-37.

44. Siegel R, DeSantis C, Virgo K, Stein K, Mariotto A, Smith T, Cooper D, Gansler T, Lerro C, Fedewa S, Lin C, Leach C, Cannady RS, Cho H, Scoppa S, Hachey M, Kirch $\mathrm{R}$, Jemal A, Ward E: Cancer treatment and survivorship statistics, 2012. CA Cancer J Clin 2012, 62:220-241.

45. Jemal A, Center MM, DeSantis C, Ward EM: Global patterns of cancer incidence and mortality rates and trends. Cancer Epidemiol Biomarkers Prev 2010, 19:1893-1907.

46. Arrieta O, Cardona AF, Federico Bramuglia G, Gallo A, Campos-Parra AD, Serrano S, Castro M, Avilés A, Amorin E, Kirchuk R, Cuello M, Borbolla J, Riemersma O, Becerra H, Rosell R, CLICaP: Genotyping non-small cell lung cancer (NSCLC) in Latin America. J Thorac Oncol 2011, 6:1955-1959.

47. Campos-Parra AD, Zuloaga C, Manriquez ME, Avilés A, Borbolla-Escoboza J, Cardona A, Meneses A, Arrieta O: KRAS Mutation as the biomarker of response to chemotherapy and EGFR-TKIs in patients with advanced non-small cell lung cancer: clues for its potential use in second-line therapy decision making. Am J Clin Oncol, in press

48. Korf BR, Rehm HL: New approaches to molecular diagnosis. JAMA 2013, 309:1511-1521.

49. Yao $S$, Zhu $Y$, Chen $L$ : Advances in targeting cell surface signaling molecules for immune modulation. Nat Rev Drug Discov 2013, 12:130-146.

50. Chung C, Christianson M: Predictive and prognostic biomarkers with therapeutic targets in breast, colorectal, and non-small cell lung cancers: a systemic review of current development, evidence, and recommendation. J Oncol Pharm Pract 2014, 20:11-28.

51. Li T, Kung HJ, Mack PC, Gandara DR: Genotyping and genomic profiling of non-small-cell lung cancer: implications for current and future therapies. J Clin Oncol 2013, 31:1039-1049.

52. Cagle PT, Allen TC: Lung cancer genotype-based therapy and predictive biomarkers: present and future. Arch Pathol Lab Med 2012, 136:1482-1491.

53. Minimum Wages Laws in the States - Wage and Hour Division. United States Department of Labor. [http://www.dol.gov/whd/minwage/america. htm\#Consolidated]

54. Salarios Minimos - 2014. Servicio de Administracion Tributaria [http://www.sat.gob.mx/informacion_fiscal/tablas_indicadores/Paginas/ salarios_minimos.aspx] 
55. Hatsukami DK, Stead LF, Gupta PC: Tobacco addiction. Lancet 2008, 371:2027-2038.

56. Valdes-Salgado R, Lazcano-Ponce EC, Hernandez-Avila M: Primer Informe sobre el combate al tabaquismo. Mexico ante el Convenio Marco para el Control del Tabaco. Cuernavaca: Instituto Nacional de Salud Pública; 2005.

57. Tindle HA, Shiffman S, Hartman AM, Bost JE: Switching to "lighter" cigarettes and quitting smoking. Tob Control 2009, 18:485-490.

58. Difranza JR, Savageau JA, Fletcher K, O'Loughlin J, Pbert L, Ockene JK, McNeill AD, Hazelton J, Friedman K, Dussault G, Wood C, Wellman RJ: Symptoms of tobacco dependence after brief intermittent use. Arch Pediatr Adolesc Med 2007, 161:704-710.

59. Reynales-Shigematsu LM, Campuzano-Rincon JC, Sesma-Vazquez S, JuárezMárquez SA, Valdés-Salgado R, Lazcano-Ponce E, Hernández-Avila M: Costs of medical care for acute myocardial infarction attributable to tobacco consumption. Arch Med Res 2006, 37:871-879.

\section{Submit your next manuscript to BioMed Central and take full advantage of:}

- Convenient online submission

- Thorough peer review

- No space constraints or color figure charges

- Immediate publication on acceptance

- Inclusion in PubMed, CAS, Scopus and Google Scholar

- Research which is freely available for redistribution 